Vantage: Journal of Thematic Analysis

ISSN: 2582-7391

A Multidisciplinary Publication of Centre for Research,

Maitreyi College, University of Delhi

April 2020, Volume 1, Issue 1

Original Research Article

\title{
Representing the LGBTQ+ Community: A Study of Indian and American Popular Culture in the Last Decade
}

\author{
Manukriti, MaumilMehraj and Amrita Ajay*
}

Department of English, Maitreyi College, Chanakyapuri, New-Delhi-110021

*Correspondence: amritaxajay@gmail.com

\begin{abstract}
Two discourses merit discussion in popular culture today: society's attitude to alternate gender identities of the LGBTQ+ spectrum, and whether forms of mass media should bear the social responsibility of equal representation for all. The conversation hinges on how society represents its gender/sexual minorities, and what that, in turn, reflects about the said society. This paper is a cross-cultural examination of these aspects in American and Indian popular cinema and web-series of the last decade. Through a close cultural analysis of select movies and webseries, the status of queer acceptance in both these countries, the secondary areas that the productions engage with, and the gender-roles assigned to queer couples have been examined. This paper argues that there are overarching similarities between the Indian and the American productions in terms of their choice of actors, the internal dilemmas of the characters represented, and their strong 'educational' intent. However, despite the global dominance of American mass culture, Indian representations and their reception by the audience also shows important deviations.
\end{abstract}

Keywords: LGBTQ+, Cinema, Hollywood, Bollywood, Gender, Popular Culture.

\section{INTRODUCTION}

The cultural symbolism of same-sex relationships had not always revolved around the idea of immorality and has been seen as a representation of the diversity of human nature. In ancient Indian society, sexuality was very much a part of the daily discourse, and even given a reverential status in art. The imposition and subsequent acceptance of the British colonial value system has bestowed India with historical and cultural multiplicities. This has complicated the idea of 'morality' and the discourse of alternate sexualities.

Sexuality was a fluid concept in ancient times as compared to modern human civilization: it was not abrogated, nor was it treated as a mental disease. Homosexuality was labelled a 'sin', a 'deviance' or sometimes even 'criminal' only subsequently in history (Bullough, 2019). 
Arguably, in this regard, India has witnessed a cycle. While the ancient attitude to alternate sexuality was progressive, there was an enormous decline in the middle colonial period, and we seem to be now faced with the challenge of reclaiming the better parts of our history that point towards social justice and inclusivity.

In the nineteenth-century, curiosity about alternate sexualities rose in the medical and social circles in the West. However, gradually, as a result of constant historical, social and political struggle, the label of criminality from the queer community has been done away with in most parts of the world. For mutual support, the community came together under an umbrella of diverse identities: Lesbain, Gay, Bisexual, Transgender and Queer (LGBTQ). Today it has further expanded to include Intersexuals and Asexuals/Allies, thereby leading to the coinage LGBTQIA or LGBTQ+.

In June 1969, riots broke out in the Stonewall Inn of the Greenwich Village of New York after the police raided a gay bar known to hold a festival of revelry involving cross-dressing. The Chicago Gay Liberation Front organized a march against this oppression on Saturday, June 27, 1970. This was to later become the 'Pride Parade'. Kolkata, in India, was the first South-Asian city to organize a Pride Parade in 1999. On August 16, 2008, the gay community of Mumbai held its first ever formal Pride Parade, and demanded India's anti-gay laws to be amended. The Delhi High Court decriminalized homosexual intercourse between two consenting adults on July 2, 2009, but this was reversed in 2013 under pressure from strong conservative and religious groups. After subsequent appeals, in 2018, the decision to decriminalize parts of Section 377 by the Supreme Court of India, was received with widespread acclaim.

In the past decade, American and Indian popular culture has moved towards more innovative and objective representations of different members of the LGBTQ+ community in popular cinema and web-series. The global influence of American popular culture has ramifications for forms of cultural production in other parts of the globe - especially in complex societies like India which has its own structural inequalities.

\subsection{Literature Review}

The LGBTQ+ community has been thoroughly studied through its history, movements, religious implications and popular culture. This literature review defines the scope and need of the project.

Ruth Vanita (2005), Leila Rupp (2009) and Susan Stryker's (2008) work is foundational in evaluating the status of sexual minorities. Lilian Faderman's (2015) account of gay liberation 
movements and Matthew Riemer and Leighton Brown's (2019) photographic history are valuable documents of the struggle.

While Robert Everett et al's (2013) edited anthology explored the status of queers within Christianity, Amara Das Wilhelm' (2003) work locates the complexity of these debates within Christianity and Hinduism for the transgender community. Dean Spade (2011) and Arvind Narrain (2004) take the legal debates about queer identities into question and highlight important landmarks. Nikki Sullivan (2003), Judith Butler (1990) and Jack Halberstam (2011) provide theoretical contexts to the intersections between gender and queer studies.

Merle Miller (1971) and Laxmi Narayan Tripathi (2015) have engaged with popular cultural representations for a wider audience. International academic publishers like the Duke University Press have a dedicated Journal of Lesbian and Gay Studies since the early 1990s. The popular Gaylaxy Magazine in India also caters to the local LGBTQ+ community.

B. Ruby Rich (2013), GiladPadva (2014) and Barbara Mennel (2014) discuss American filmography at length, but in India research on Indian queer cinema is still a fledgling field. This paper attempts to fill in the gap by analysing last decade's popular culture, cinema and web-series to understand the American influence on Indian LGBTQ+ representations. This comparative assessment has not been attempted before and illumines several nuances of culture and politics.

\section{METHODOLOGY}

The methodology of this research will be a comparative cultural and gender analysis between Indian and American media representations of the LGBTQ+ community - in cinema as well as web-series. The research will be limited to the productions spanning the past decade (20092019) and available in English and Hindi, owing to their accessibility for the authors. Regional and independent cinema have also made valuable contributions to queer studies, but the focus of this paper is on the dominant culture industries of Hollywood and Bollywood. It is important to look at these two forms of cultural production in juxtaposition to each other to understand the underpinnings of the politics of representation in popular culture.

Through a close reading of the narratives and ideologies in the select movies, web-series, and theoretical works, using tools from Cultural Studies, Gender and Queer Studies, and Film Studies, an assessment is made regarding the forms of production and consumption of these media. This will be a qualitative analysis of the primary and secondary texts to map patterns of similarity and deviance, and inferences will be drawn from them.

Following is a list of all primary texts: 
List of Films (American):

- 2016: Moonlight

- 2017: Call Me by Your Name

- 2018: Boy Erased

- 2018: Love, Simon

List of Web-Series (American):

- 2013: The 3 Bits (mini-series of three episodes)

- 2017: Build a Boo (mini-series of five episodes)

- 2013-19: Orange is the New Black (Seasons 1-7)

List of Films (Indian):

- 2008: Dostana

- 2011: I Am

- 2014: Margarita with a Straw

- 2015: Aligarh

- 2018: Ek Ladki Ko Dekha Toh Aisa Laga

List of Web-Series (Indian):

- 2019: Made in Heaven (Season 1)

- 2018: Sacred Games (Season 1)

- 2018: Four More Shots Please! (Season 1)

These productions have been chosen because of their popularity, critical acclaim, linguistic accessibility and audience reception. They are only seen as representative and not exhaustive. This paper seeks to assess various kinds of media representations and their importance for queer identities. It attempts to quantify the media presence of the LGBTQ+ community in both India and America and analyze the consumption patterns to gauge their popularity. The social, economic, religious, or cultural background of the queer characters have been assessed to see what it reflects about communities and social attitudes. The qualities of essentialised masculinity and femininity are examined in these characters in relation to heterosexual norms. The coding of queer identity in everyday experiences is examined for its representation of 'normalcy'. The reductive stereotyping through body language or dialogues are closely assessed and compared to progressive representations in both cultures. Finally, the global impact of such representation is analyzed in terms of how societies and cultures are depicted. The politics of narration and ideology underlie all these questions.

\section{DISCUSSION AND ANALYSIS}




\subsection{American Representations of the LGBTQ+ Community}

\subsubsection{Cinema}

\subsubsection{Moonlight (2016)}

Based on the unpublished, semi-biographical play, In Moonlight Black Boys Look Blue by Tarell Alvin McCraney, Moonlight captures Chiron's life from childhood to adulthood depicting three stages of his life as a black, gay man living in Miami, Florida. Black masculinity and identity is the central theme, in the backdrop of drug abuse. Moonlight "passes through love, sex, survival, mother and father figures, the last one foregrounded by the poignant absence of the fathers themselves" and establishes the feeling of being different in a spectacular manner (Bradshaw, 2017).

According to B. C. Mennel,

"Masochism as an aesthetic and psychic structure challenges us to rethink some of our most basic assumptions regarding power, pleasure, and domination, particularly how these kinds of assumptions are articulated in the study of the humanities" (2007)

Moonlight moves away from the stereotypes when representing the emotional quotient of the black macho-man. It presents the "feminine-male" portion of the black community that is hardly represented. Through "visually ravishing dream sequences, epiphanic surges, hallucinatory close-ups, lush swathes of music" (Hornaday, 2016) the narrative dignifies the people of colour and brings their stories to the forefront, suggesting a willingness "to show young LGBT people the levels of happiness, potential and positivity their lives will reach - if they can just get through their teen years" (Johnson, 2014). Chiron passes through this journey, retrospectively, to abstractly present the idea of self-liberation and acceptance.

The film attempts not just representation but goes on to highlight the psychological consequences of homophobia and bullying. By breaking the mould of the black male stereotype and foregrounding the struggles of the community, Moonlight covers more terrain as an LGBTQ+ movie, which brought well-deserved critical acclaim to the film (though, not enough commercial returns).

\subsubsection{Call Me By Your Name (2017)}

Based on Italian writer Andre Aciman's book by the same name, Call Me By Your Name (2017) is set in the year 1983 (Aciman, 2007). Directed by Luda Guadagnino, it narrates a summer romance between Elio and Oliver. During its premiere at the Sundance Film Festival, it 
received the longest standing ovation which brought this independent film to mainstream (Evans, 2017). The plot is a curious and sensitive examination of first love, sexual exploration and desire through a beautiful aesthetic.

In Edmund White's short story Cinnamon Skin, the protagonist contends that teenagers have a desire "too general to respond to anything less than eternal love and their love is vague and powerful enough to ennoble anybody at all" and how "people are wrong to imagine teenage boys want to shoot their loads; what they want is a union of souls which will only incidentally result in a tangling of arms, thighs, loins" (Padva, 2015).

These psychological truths echo in Elio whose love is purely sensual. The narration is primarily focused on Elio's bildung, while also capturing the extent of beauty. Mennel observes that "Sexuality and gender played a central role in the history of the film, even before feature-length narrative film developed because the medium engages the different pleasures of looking and being looked at: voyeurism and exhibitionism." (Mennel, 2012). While this was initially true of the heterosexual male voyeurs and female exhibitionists under gender constraints, here Elio is a voyeur and Oliver is the exhibition that he observes, understands and longs for.

The symbolic use of water, family dynamics, ideas of love (above and beyond gender/age) help the film mark the emotional, intimate and self-exploratory aspects of a queer person, which makes it a landmark in representing parts of the LGBTQ+ community.

\subsubsection{Love, Simon (2018)}

M. J. Franklin observes(2018), Love, Simon balances all of those elements: it's a heartwrenching, empathy-expanding look at what it means to be a gay teen and it's a universal story about the awkward, messy attempts of navigating high school, and it's a hilarious comedy in its own right .

Narrated from the perspective of a teenager, the movie raises questions about being gay and questions stereotypes like that of only homosexuals "coming out" to their families. Conflicts arise and fall as Simon develops as a character, complete with a beautiful accepting speech by his mother at the end of the film. Love, Simon brings a much needed "gay rom-com" to the mainstream.

Two decades ago, B. Ruby Rich notes, the queer audiences wanted to be primarily entertained. She expresses dissatisfaction regarding the content available: 
I'm still waiting along with the rest of you to see the long-promised crossover movie that pleases "us" as well as "them" and makes a bundle of money -the cranky critic in me remains unsatisfied. (2013)

Love, Simon seems to have reached that mark of honour, marketability, with a strong sense of characterisation. While presenting Simon's struggles, the specific political motives presented in previous decades have given way to a delightful, sweet story that shows the evolution of the genre and audience sensibilities.

\subsubsection{Boy Erased (2018)}

Gay conversion therapy is all about the destruction of the self - "a mental, philosophical, and allegedly spiritual re-education camp" that repeatedly denies a person's reality (Salvov, 2018). Based on Garrard Conley's memoir, Boy Erased is the depiction of the horrifying conversion therapy and a conservative society's perspective on queer identity (Conley, 2016). Through the journey of Jared Eamons and his experiences at the conversion centre, we are offered an insight into religious conflicts around the queer identities

Representing a social message, it touches the inner-workings of Jared's mind, his family and similar people stuck in similar conditions. The setting is heartbreaking and the conversations between him and his parents, who work at their own pace to accept Jared, brings important insight into the confusion created through religious beliefs in people about homosexuality.

\subsubsection{Web-Series}

\subsubsection{Orange Is the New Black (2013-19)}

Based on Piper Kerman's memoir, Orange Is the New Black: My Year in a Women's Prison (2010), this Netflix-original series revolves around Piper Chapman, who serves a year in prison. The series has thirteen characters that represent the community (Cook, 2018). Sophia Burset's character is highly acclaimed and is played by a real-life transgender woman. Class and age also play an important role in the representative lesbian population on the show. Class affects each character, as they move throughout the system of imprisonment: struggling for money, facing racism and being put through confinement for petty reasons.

The span of the show is vast, and thus, captures a wide timeline and social spectrum. During the course of the show, same-sex marriage was legalized in the USA and the queer population felt more liberated and victorious (Chapell, 2015). Jill Gutowitz notes how the series continously "allowed for queer women of color to be included in prestige television, both on- 
screen and behind the camera, rather than being restricted to frothier fare" - which stands testimony to the show's major success (2019).

The web-series has depicted a realistic portrayal of each relationship in the course of seven seasons. Being sensitive, working on specific character arcs, it became one of the most viewed shows on Netflix. Offering better representation to the LGBTQ+ community, people of colour and tapping on themes of immigration and politics, it diversifies and complicates with new perspectives in popular heternonormative productions.

\subsubsection{Build a Boo (2017)}

Creator Michelle A. Daniel's Build a Boo is an independent project, produced by The DAMN Network. The story revolves around simple issues of two black women, where Taylor is straight and Ava is gay. The show presents romantic relationships and their repercussions through subtle representations, elements of comedy and a dramatic premise.

Ava is generally a "crazy" character, and the show normalises the existence of complications in all relationships, not just heteronormative ones. Her partners are disparate: one has low selfesteem, another experiences new sexual fluidity, while still another is a married woman cheating on her husband.

The collaborative effect that these representations have is to search and portray each kind of femininity and sexuality, which makes the show an important signifier of the potential of small, broadcasting services' content, and not just big OTT platforms.

\subsubsection{The 3 Bits (2013)}

Being a queer web-series, this story of three siblings (out of which two are queer) is short but specific, and conveys the freedom of open, unattached sexuality, among other themes. With nine episodes in total, and being a small-scale project where the actors even worked for free, there is not much attention offered to the series. However, the show represents free, almostadult characters, going through dates, wanting to have sex, and engaging in drug use, which makes the series remarkably real and gritty.

The web-series represents the importance of YouTube and other crowd-funded projects for the LGBTQ+. It allows an insight into the workings of media and youth culture. We can ascribe the success of this project to queer theorist B. Ruby Rich's idea that ideologies that go back to the video camera generations and wish for the content to be less political and more relatable have now found a space (2013). The 3 Bits, thus, succeeds in normalising the existence of queers even in a small scale of production. 


\subsection{Indian Representations of the LGBTQ+ Community}

\subsubsection{Cinema}

\subsubsection{Dostana (2008)}

Although released in 2008 (a year before this research's purview), Dostana is important because it was one of the first large-scale Bollywood movies that dealt with the theme of homosexuality overtly. The Guardian observed, "Now India's convoluted attitude to gayness finally has its cinematic manifestation in Dostana (Friendship), one of the gayest films ever made in any our country but in which almost no one is actually gay. It's also a terrific movie - the best and funniest Bollywood film I've seen in a very long time (Dhaliwal, 2008)".

The story is also set in an American context to raise fewer questions about social acceptance. The caricaturish representation of heterosexual men pretending to be gay, in order to woo a girl, couches the question of respresenation and marketing in very problematic terms.

\subsubsection{I Am (2011)}

I Am is a film divided into four stories - in I Am Omar, the gay character has intercourse with a man at a public place and they are caught by a mercenary policeman in the act. This happens at a time when under Section 377 of the Indian Penal Code, same-sex intercourse was a criminal offence. After bribing the policeman, and finding a lawyer, it is revealed, the character's partner and the policeman had set the scene up to extort money from him.

The film is painfully realistic in terms of depicting the emotional and structural struggles that homosexuals encounter, and the failure of the law to provide amnesty to them. I Am received critical acclaim, but it was not popular among audiences.

\subsubsection{Margarita with a Straw (2014)}

According to Deepanjana Pal (2015), "The clear distinction between a lesbian and bisexual is a feat achieved by this film because it clearly and aptly represents not one, but two people identifying in different ways with the LGBTQ+ community".

The film charts the journey of a college student who discovers her sexual inclinations, except, she suffers from cerebral palsy. The lead character is curious when it comes to sex, watches porn, and masturbates. She is in a relationship with a girl, but ends up having intercourse with a boy, bringing not just lesbianism, but bisexuality to the table.

One critique would be that the methods of sexual intercourse are not talked about in an educational manner, as the person involved is not in control of their motor skills. But the representation of the 
LGBTQ+ has taken many strides ahead in this film made for Indian audiences. The combination of bisexusality, disability and female desire are uncharted terrains in mainstream Indian cinema, and are thus vital to the changing popular discourse and audience taste.

\subsubsection{Aligarh (2015)}

Aligarh is inspired by the real-life ordeal of a 64-year-old Professor, who was suspended by the Aligarh Muslim University for being homosexual. Caught in the act of intercourse with a lover by the media, he is ostracized by his entire social and academic circle for an act that was criminalised by the IPC. The Professor then forms a friendship with a young journalist, who aids him in the process of seeking legal help, and the court, in turn, rules in his favour and his suspension is revoked. But before he can return to work, he is found dead. This hints towards perhaps a suicide, instigated by homophobia and mob culture.

Aligarh is, according to C. Rajinder Sawhney (2015), "probably the best film yet on the Indian gay male experience, Hansal Mehta directs a riveting and nuanced tale that is as touching as it is powerful". While decriminalising homosexuality is an underlying message, the film essentially revolves around companionship and loneliness. The question of class also becomes significant as the relationship between a college professor and a poor rickshaw-puller becomes an unconventional space to explore alternate sexuality.

\subsubsection{Ek Ladki Ko Dekha Toh Aisa Laga (2018)}

As a mainstream Bollywood film, with big stars playing lead characters, this movie brings lesbianism in small towns to the forefront.

Ek Ladki Ko Dekha Toh Aisa Laga is an attempt at "normalising" everyone who is

"not normal" ... The Lihaafs that are persecuted and the Goblin Markets that men don't want. (Bhattacharya, 2019)

Although a much-sanitised version, with not even a kissing scene, the film attempts to fit the unconventional love-story into a Bollywood-style romance drama. Despite the popular songs and sentimentalisation of love, the story manages to present relatively 'real' lesbian characters, albeit aided by a hero to 'save the day'. The challenge of female sexuality to patriarchy is approached gingerly. Saibal Chatterjee (2019) notes of the film that, "it does not seek to derive mirth and frivolity from the theme, offering instead an earnest, unapologetic depiction of the act of coming out in a conservative society". 


\title{
3.2.2 Web-series
}

\subsubsection{Sacred Games (Season 1) (2018)}

Based on a crime thriller novel by Vikram Chandra (2006), the LGBTQ+ portrayal comes out in the form of the love interest of the main antagonist who is a transgender bar dancer. What is remarkable in this portrayal is that she (the transgender character) is made independent of her sexuality, and is loved because of how robust and devoted her character is shown to be.

[The character] becomes more real to us because she is loved, and respected, because he [the love interest] doesn't change the way he looks at her, after he learns that her assigned sex is different from her gender identity. (Dey, 2018)

The production is gritty and realistic. With the reduced censorship of the internet, as opposed to cinema that has to go through a rigid censor and certification process, there is more creative freedom in the depiction of minority characters like Kuku.

\subsubsection{Four More Shots Please! (Season 1) (2018)}

Touted as India's version of Sex and the City, Four More Shots Please tries to break stereotypes about modern, urban women, but instead ends up promoting them. Tanika Godbole observes (2019) "The chubby girl is the virgin. The bisexual is the overtly sexual one who is constantly hooking-up with someone. The divorced mother is the one who has never explored masturbation. And the careerminded startup owner is the obsessive-compulsive loner".

Despite its popularity as a show that embraces bisexuality, it completely ignores gay stereotypes portrayed through several dialogues of the show.

\begin{abstract}
...[M]ohit, here tells her that the empire line doesn't suit her. A straight guy who knows about fashion? It is not possible and doesn't exist. And this is how the show introduces its gay character. And when Mohit hits on a straight man, the latter states his interests as "watching sports and playing video games" immediately establishing the fact that he's straight. (Sharma, 2019)
\end{abstract}

\subsubsection{Made in Heaven (Season 1) (2019)}

Made in Heaven shows its audience the upscale, modern India, where a woman co-runs a wedding planning business with a man who identifies as gay. Refreshingly, the gay character is portrayed as a normal, sensible man.

A closeted gay man drowning in debt and personal conflicts, his identity is beyond the stereotypical gay men Indian filmmakers have often thrown at us. Despite being 
aware of the taboo he has to live with every single day, he doesn't perceive his sexuality as a burden. (Shukla, 2019)

This is despite the threat and attacks from conservative political groups. There is also a repressed gay landlord whose tragic denial of his identity is portrayed with complexity and empathy.

Although these productions have a distinct way of representing the queer community, none of the actors, interestingly, who play these characters, identify with the LGBTQ+ gender spectrum in real life.

\subsection{Comparative Analysis}

\subsubsection{Casting of actors in queer roles:}

In Indian productions of both movies and web-series, all actors playing queer characters were cis-gendered. Similar is the case with American productions, where only one transgender character is played by a transgender woman. This is a rarity on screen, and consequently the actual queer and transgender community remains unrepresented as actors on-screen.

Both cis-gendered and queer actors confirmed that it was not their sexual identity but their acting aptitude that determined their selection. This, however, makes us question how much and how real LGBTQ+ representation is, and whether mainstream media must take the onus of such social representation.

\subsubsection{Social Awareness:}

There is a steady attempt at increasing the educational value of Indian productions and a major step-ahead is seen in this domain. From Dostana's caricaturish portrayal of gay men in the guise of humour, to later sensitive representations like Made in Heaven, there is a more progressive understanding of queer identity and its normalcy. The social settings of the movies and web-series also change the societal depiction where the people around the queer/transgender characters are not entirely baffled by the existence of their sexuality.

Contrary to this trend, American society seems to have previously gone through the process of queer representation and acceptance, and now focuses on a higher level of education which deals with nuanced psychological aspects of queer characters. Nevertheless, therapy or postconversion procedures are also highlighted in the American context, which showcase the challenges still faced by alternate genders and sexualities.

What is interesting to note here, is that documented queer communities were formed in America as late as 1969. But ancient Indian mythological texts and temples have depicted homosexuality since times immemorial, but were subsequently criminalised in the modern era 
(Dasgupta, 2011) This subversion can be attributed to various aspects, including the Islamic invasion of the Indian subcontinent, and British colonisation, which led to a hybrid culture.

[In] many countries, 'culture' itself is embattled terrain; and India is no exception. This is due, partly, to the sheer size of the country, the number of languages, dialects, regions, religions, beliefs, and caste practices. It is also due, partly, to colonialism, and the national liberation struggle, vicious and unrelenting caste, class, and gender opposition, violent and xenophobic mobilisation of religious, ethnic, and linguistic sentiments, the ways in which the country was partitioned, and is governed, with all the ensuing material and psychic repercussions for individuals, communities, and the polity. (Butler, 1996)

\subsubsection{Reception by the audience:}

In India, more nuanced films (like $I \mathrm{Am}$ ) generally did not do as well as typical big-budget Bollywood movies or stereotyped queer movies (like Dostana). It could possibly be argued that Indian consumers are not ready for this kind of exhibition of sexuality, given the society's complex historical and social background. This might hold true for other Bollywood movies, too, who come with a strong social message since cinema is mostly looked at as a form of entertainment.

American films, on the other hand, are taking a stand on issues of immense social importance and thus are able to target a vast audience due to economic and cultural factors. The themes of LGBTQ+ are undercurrents to the main storyline and not the primary focus of such movies. American web-series have the same outlook. Besides, the discourse about alternate genders has been going on in America for a long time, and being gay is no longer an alien idea to them, relatively.

\subsubsection{Media Consumption and Cultural Economy:}

Art and cultural production have a strong market motive. Bollywood movies dealing with queer communities did not do so well in terms of revenue-generation and were not as successful as other mainstream movies. The reward for queer-representative movies is critical, and not monetary. Hollywood movies, however, managed to earn critical as well as popular acclaim, while also gaining commercial success.

What is interesting to note here is that web-series are more autonomous because they are not as heavily monitored by the censorship and certification authorities. Entertainment is different 
based on where it is being consumed - in the public space of the theatre, or in the privacy of an individual's personal space (through their PCs, smartphones, etc.). While movies are limited by the shared spaces they are experienced in, no such restrictions burden web-series. The internet allows unlimited access to content, while also maintaining the consumer's privacy/anonymity. The debate here, therefore, would be whether OTT consumption, over boxoffice collection, is the real judge of popularity/merit.

\subsubsection{Social background of the queer characters:}

The characters in Indian productions come from different economic and cultural backgrounds which indicates that queer identities are not delimited by class, caste or ableism. There is freedom of expressing one's sexuality only in the upper class, as evidenced in Dostana and Made In Heaven, while lower-class characters bear the brunt of social disapproval more harshly.

The American characters follow a similar pattern, where coloured people, the elite educated class, the conservative Christian, and the modern urban lower-middle class are equally represented. The social backgrounds in both cultures are refreshingly diverse and inclusive.

\subsubsection{Thematic preoccupations:}

The Indian movies and web-series are either politically driven, given same-sex intercourse was a legal offence under section 377 of the Indian Penal Code until recently, or they are trying to normalise being queer or transgendered. The movies focus on the individual and society, while web-series often take a route where queer characters play supporting roles to bring the story to its destination. They are seldom main leads.

American productions concentrate on individual psychology/struggles/character arcs, which often includes their immediate family. According to popular cultural representations, American society seems to have made peace with the idea of LGBTQ+ existence, and is striving to make their presence normal, which is still lacking in the Indian context.

\subsubsection{Gender roles within queer relationships:}

Both in the Indian and American productions, we see how gender roles come into play. The gay couple has an outwardly masculine character who is supposed to be the 'man' in the relationship and a somewhat effeminate character who plays the 'female' role. Similarly, in a lesbian relationship, the more imposing character is shown as masculine, and vice-versa. 
There is no original or primary gender a drag imitates, but gender is a kind of imitation for which there is no original (Butler, 2006). Because the idea of heteronormativity is ingrained into the minds of people, we still tend to formulate a man-woman quotient in homosexual relationships. There seems to be no room for two feminine women, or two equally masculine men, to be involved in a romantic relationship with each other.

\subsubsection{Patriarchy and Queerness:}

Even within alternate genders/sexualities, there exists a hierarchy where gays are given prominence, followed by lesbians, bisexuals, and finally transgenders. This is true of both Indian and American popular culture. While it will be contentious to say this is done intentionally, it is a pattern that repeatedly emerged throughout this study. This implies that patriarchal norms underpin representations even within queer communities, and ought to be questioned.

\section{CONCLUSION}

Through the study of our selected primary material, it would be credible to say that the global LGBTQ+ community has moved collectively ahead by accepting its identity and gaining increasing acceptance and representation in a predominantly heterosexual world of media portrayals.

In the last decade, American films have paid attention to the psychology of the LGBTQ+ members while also highlighting social factors that influence it. Exploring homosexuality within wider contexts allows more creative freedom and equitable representation. On the other hand, Indian films use strong political and social backgrounds to convey a moral and educational message, which the American societies seem to have already done. The question of the entertainment industry's restrictions on these cultural productions is overarching.

Web-series as a genre/medium are allowing more freedom than cinema to its creators and audience. In this, both American and Indian popular culture, stand side-by-side. However, there is still a gendered understanding of alternate sexualities prevalent in popular culture that needs to be challenged.

\section{CONFLICT OF INTEREST STATEMENT}

Manukriti, Maumil Mehraj and Amrita Ajay declare that they have no conflict of interest. 


\section{SOURCE OF FUNDING}

This paper was supported by Maitreyi College.

\section{ACKNOWLEDGEMENTS}

This research project was undertaken as part of the Summer Internship Project2019, under the aegis of the Centre for Research at Maitreyi College, over the duration of two months. We are extremely grateful to the Principal and members of the Centre for Research for allowing us this wonderful opportunity to conduct such intensive research within a multi-disciplinary framework.

\section{REFERENCES}

Aciman, A. (2007). Call Me By Your Name. London: Atlantic Books.

Bhattacharya, A. (2019). Ek Ladki Ko Dekha Toh Aisa Laga Movie Review: Sonam Kapoor powers excellent lesbian love story. India Today. Retrieved from https://www.indiatoday.in/movies/reviews/story/ek-ladki-ko-dekha-toh-aisa-laga-moviereview-sonam-kapoor-anil-kapoor-1444376-2019-02-01

Bradshaw, P.(2017). Moonlight Review - a visually ravishing portrait of masculinity. The Guardian.

Retrieved from https://www.theguardian.com/film/2017/feb/16/moonlight-review-masculinitynaomie-harris

Bullough, V. L. (2019). Homosexuality: A History (From Ancient Greece to Gay Liberation). (Volume II). New York: Routledge.

Butler, J. (1990). Gender Trouble. (1st ed).New York: Routledge.

Butler, J. (1996). Imitation and Gender Insubordination. In Garry, A., \& Pearsal, M. (ed.), Women, Knowledge, and Reality: Explorations in Feminist Philosophy. (2nd Ed.) New York \& London: Routledge.

Chapell, B. (2015). Supreme Court Declares Same-Sex Marriage Legal In All 50 States. National Public Radio. Retrieved from https://www.npr.org/sections/thetwoway/2015/06/26/417717613/supreme-court-rules-all-states-must-allow-same-sexmarriages

Chatterjee, S. (2019). Ek Ladki Ko Dekha Toh Aisa Laga Movie Review: Sonam, Anil Kapoor's Film Is A Whiff Of Fresh Air With Daring Vision And Entertainment. NDTV. Retrieved from https://www.ndtv.com/entertainment/ek-ladki-ko-dekha-toh- 
aisa-laga-movie-review-sonam-anil-kapoors-film-is-a-whiff-of-fresh-air-4-stars1986640

Conley, G. (2016) Boy Erased: A Memoir. New York: Riverhead Books. Cook, C. (2018). A content analysis of LGBT representation on broadcast and streaming television. Honours Theses. https://scholar.utc.edu/honors-theses/128

Dasgupta, R. K. (2011). Queer Sexuality: A Cultural Narrative of India's Historical Archive, Rupkatha Journal on Interdisciplinary Studies in Humanities, 3(4), 651-667. http://rupkatha.com/V3/n4/20_Queer_Sexuality_India.pdf

Dey, S. (2018). We Finally Have Cuckoo, the Gorgeous Transgender Heroine of Netflix's Sacred Game. News $18 . \quad$ Retrieved from https://www.news18.com/news/lifestyle/we-finally-have-cuckoo-the-gorgeoustransgender-heroine-of-netflixs-sacred-games-1811641.html

Dhaliwal, N. (2008). Dostana is a straight victory for gay comedy. The Guardian. Retrieved from https://www.theguardian.com/film/2008/dec/03/bollywood-dostana.

Evans, G. (2017). 'Call Me By Your Name’ Trailer Gives First Look At Sundance Fest Hit. Deadline. Retrieved from https://deadline.com/2017/08/call-me-by-your-nametrailer-first-look-sundance-festival-1202140292/

Faderman, L. (2015). The Gay Revolution: The Story of Struggle. (1st ed). New York:Simon \& Schuster.

Franklin, M. J. (2018). 'Love, Simon' is a gotdamn delightful romcom, and it's gay as hell. Mashable India. Retrieved from https://mashable.com/2018/02/27/love-simon$\underline{\text { review/ }}$

Garry, A., \& Pearsal, M. (ed.) Women, Knowledge, and Reality: Explorations in Feminist Philosophy. (2nd Ed.) New York \& London: Routledge.

Godbole, T. (2019). Four More Shots Please Review: Glass Half Full. Feminism in India. Retrieved from https://feminisminindia.com/2019/02/01/four-more-shots-please-review/

Gutowitz, J. (2019). Orange Is the New Black Made TV—and Me-Gay. Time. Retrieved from https://time.com/5630333/orange-is-the-new-black-queer-revolution-tv/

Halberstam, J. (2011). The Queer Art of Failure by Judith (now Jack) Halberstam. (1st ed). Durham and London: Duke University Press.

Hornaday, A. (2016). Moonlight' is both a tough coming-of-age tale and a tender testament to love. The Washington Post. Retrieved from https://www.washingtonpost.com/goingoutguide/movies/moonlight-is-both-atough-coming-of-age-tale-and-a-tender-testament-to-love/2016/10/27/45d88eea- 
9b80-11e6-9980-

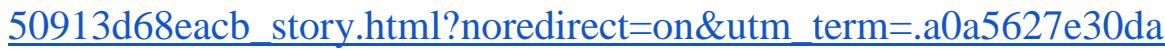

Johnson, M. J. (2014). The It Gets Better Project: A Study in (and of) Whiteness - in LGBT Youth and Media Cultures in Queer Youth and Media Cultures. In Pullen, C. (ed.) Queer Youth and Media Cultures. (1st ed). UK: Palgrave Macmillan. (pp. 278).

Kerman, P. (2010). Orange Is the New Black: My Year in a Women's Prison. New York: Spiegel \&Grau.

Mennel, B. C. (2007). The Representation of Masochism and Queer Desire in Film and Literature. (1st ed). New York: Palgrave Macmillan US. (pp. 1).

Mennel, B. C. (2012). Queer Cinema: Schoolgirls, Vampires, and Gay Cowboys (Short Cuts). (1st ed). London:Wallflower Press. (pp. 2).

Miller, M. (1971).On Being Different. (1st ed). London: Penguin Books.

Narrain, A. (2004).Queer: Despised Sexuality, Law, and Social Change. (1st ed). Bangalore: Books for Change.

Padva, G. (2014). Queer Nostalgia in Cinema and Pop Culture. (1st ed). UK: Palgrave Macmillan. (pp. 1)

Pal, D. (2015) Margarita With A Straw Review: Kalki Koechlin is brilliant in this heartfelt yet flawed movie. Firstpost. Retrieved from https://www.firstpost.com/entertainment/margarita-with-a-straw-review-kalkikoechlin-is-brilliant-in-this-heartfelt-yet-flawed-movie-2198862.html

Pullen, C. (ed.) (2014). Queer Youth and Media Cultures. (1st ed). UK: Palgrave Macmillan.

Rich, B. R. (2013). New Queer Cinema: The Director's Cut. (1st ed). UK: Duke University Press Books. (pp 40-42)

Riemer, M., \& Brown, L. (2019). We Are Everywhere: Protest, Power, and Pride in the History of Queer Liberation. (1st ed). California: Ten Speed/Harmony/Rodale.

Revathi, A. (2010). The Truth About Me: A Hijra Life Story. (1st ed). New Delhi: Penguin Books.

Rupp, L. (2009). Sapphistries: A Global History of Love between Women. (1st ed). New York: New York University Press.

Salvov, M. (2018). Boy Erased Review. Austin Chronicle. Retrieved from https://www.austinchronicle.com/events/film/2018-11-08/boy-erased/

Sawhney, C. R. (2015). Aligarh. What's On. The British Film Institute. Retrieved from https://whatson.bfi.org.uk/lff/Online/default.asp?BOparam::WScontent::loadArticle::perm alink=aligarh\&BOparam::WScontent::loadArticle::context_id= 
Sharma, T. (2019). 4 Reasons Why Four More Shots Please Misses The Mark. Feminism in India. Retrieved from https://feminisminindia.com/2019/02/08/four-more-shots-please-missedmark-review/

Shore-Goss, R. E., Bohache, T., Cheng, P. S., \& West, R. F. (2013). Queering Christianity: Finding a Place at the Table for LGBTQI Christians. (1st ed). Santa Barbara, CA: Praeger.

Shukla. P. (2019). 'Made in Heaven': A Milestone in Depiction of Gay Characters. The Quint. Retrieved from https://www.thequint.com/entertainment/hot-on-web/made-inheaven-a-milestone-in-depiction-of-gay-characters

Spade, D. (2011). Normal Life: Administrative Violence, Critical Trans Politics, and the Limits of Law. (1st ed). Durham: Duke University Press.

Stryker, S. (2008). Transgender History. (1st ed). Berkeley: Seal Press.

Sullivan, N. (2003). A Critical Introduction to Queer Theory. (1st ed). Edinburgh: Edinburgh University Press.

Tripathy, L. N. (2015). Me Hijra, Me Laxmi. (1st ed). New Delhi: Oxford University Press.

Vanita, R. (2005). Love's Rite: Same-Sex Marriage in India and the West. (1st ed). New Delhi: Palgrave Macmillian.

Wilhelm, A. D. (2003). Tritiya-Prakriti: People of the Third Sex: Understanding Homosexuality, Transgender Identity, and Intersex Conditions Through Hinduism Eleven Ways to Love: Essays. (1st ed). Philadelphia: Xlibris.

How to cite this article: Manukriti., Mehraj, M. \& Ajay, A. (2020). Representing the LGBTQ+ Community: A Study of Indian and American Popular Culture in the Last Decade. Vantage: Journal of Thematic Analysis, 1(1): 75-93.

DOI: https://doi.org/10.52253/vjta.2020.v01i01.08

(C) The Author(s) 2020.

This work is licensed under a Creative Commons Attribution 4.0 International License which permits its use, distribution and reproduction in any medium, provided the original work is cited. 